\title{
Hereditary myokymia and paroxysmal ataxia linked to chromosome 12 is responsive to acetazolamide
}

Wiebe Jan Lubbers, Ewout R P Brunt, Hans Scheffer, Mike Litt, Rein Stulp, David L Browne, Tiemen W van Weerden

\begin{abstract}
A sixth family with autosomal dominantly inherited myokymia and paroxysmal ataxia is described. The syndrome in this family is linked to the recently discovered locus for inherited myokymia and paroxysmal ataxia on the human chromosome $12 \mathrm{p}$, and a missense mutation is shown in the KCNA1 gene. The attacks of ataxia in this family compare well with those of previously described families and similarly are precipitated by kinesigenic stimuli, exertion, and startle. Responsiveness of these attacks to low dose acetazolamide is confirmed, but some loss of efficacy occurs with prolonged treatment, and side effects are notable. Although not all affected family members showed myokymia on clinical examination, electromyography invariably showed myokymic discharges, in one patient only after a short provocation with regional ischaemia. One affected family member also had attacks of paroxysmal kinesigenic choreoathetosis, responsive to carbamazepine.
\end{abstract}

(F Neurol Neurosurg Psychiatry 1995;59:400-405)

Department of

Neurology, University

Hospital Groningen, PO Box 30.001, 9700 RB Groningen, The Netherlands W J Lubbers

E R P Brunt

$T W$ van Weerden

Department of

Medical Genetics,

State University of

Groningen, A

Deusinglaan 4,

9713 AW, Groningen,

The Netherlands

H Scheffer

R Stulp

Departments of

Biochemistry and

Medical Genetics,

Oregon Health

Sciences University,

Portland, Oregon

97201, USA

$M$ Litt

D L Browne

Correspondence to

Dr E R P Brunt,

Department of Neurology,

University Hospital

Groningen, PO Box 30.001

$9700 \mathrm{RB}$ Groningen,

The Netherlands.

Received 9 February 1995

and in revised form

16 May 199

Accepted 1 June 1995 Keywords: episodic ataxia; hereditary myokymia acetazolamide

Autosomal dominantly inherited episodic ataxias can be classified in two main categories according to the presence or absence of myokymia. ${ }^{1}$ Since the first paper by Parker, familial periodic ataxia, without myokymia, has been described in about 25 families. ${ }^{23}$

Patients with familial periodic ataxia experience episodes of limb and gait ataxia, vertigo, nausea, and sometimes headache, usually lasting for hours. The attacks are brought on by emotional stress, fatigue, exercise, alcohol, carbohydrate intake, and menstrual periods. Kinesigenic provocation is uncommon, and attacks do not follow a sensory aura. As a rule, nystagmus is present both during and between the attacks. Progressive ataxia, a disorder of pyruvate metabolism, or localised atrophy of the vermis has been found in a few cases. Carbonic anhydrase inhibiting drugs such as acetazolamide and sulthiame, but also phenytoin and various other drugs are effective in the prevention of attacks. ${ }^{1-5}$

Hereditary myokymia and paroxysmal ataxia or episodic ataxia and myokymia was first described in 1975 by Van Dyke et al with additional reports of four other families. ${ }^{16-9}$ In hereditary myokymia and paroxysmal ataxia, patients experience short attacks, lasting up to 15 minutes, which consist of generalised ataxia, slowing of movements, and variably pronounced trembling or shaking. Kinesigenic provocation, often by an axial movement after a period of rest, and a short sensory warning are common. True vertigo and nystagmus are absent, both during and between attacks.

The myokymia or neuromyotonia ranges from minute movements found in relaxed unsupported fingers to obvious stiffening of the hands and feet. Sometimes EMG is needed for its detection. ${ }^{8}$ In hereditary myokymia and paroxysmal ataxia, myokymia has been shown to be of multifocal peripheral nerve origin, possibly caused by spontaneous and prolonged axonal depolarisation. ${ }^{810}$ Phenytoin is variably effective in the prevention of ataxia. ${ }^{16-8} \mathrm{~A}$ favourable response to carbonic anhydrase inhibiting drugs has not yet been confirmed, and is refuted in a recent review. ${ }^{811}$ Although phenytoin and carbonic anhydrase inhibiting drugs act similarly in the prevention of ataxia, their effect on myokymia seems to be different, as phenytoin reduced myokymia in pronounced disease, but acetazolamide and sulthiame caused an increase of stiffness in patients with less pronounced myokymia..$^{6-8}$

After localisation of the trait for episodic 
three minutes. After informed consent, DNA of affected and non-affected family members was isolated from peripheral blood and typed with the markers D12S100, D12S372, D12S1088, KCNA5, and D12S99. ${ }^{12} 13$ The effect of medication was evaluated by comparison of the number and severity of attacks in ensuing periods with and without open label treatment.

\section{DESCRIPTION OF PATIENTS}

\section{Patient 1 (IV-7)}

The proband, a 20 year old woman, had attacks of "swinging legs" and dizziness during which she experienced involuntary jerky limb movements, dysarthria, and gait ataxia. Sometimes, a sudden sensation in her neck, which within seconds spread over her body, marked the onset of an attack. First noticed at the age of 6 , the attacks occurred often three or four times daily, lasting from 10 seconds to five minutes, with varied intensity. On one occasion a prolonged attack with considerable leg jerks during a period of fever had prompted admission to hospital. Attacks happened at rest but more often occurred during exercise or when the patient was startled, standing up, running, slipping, or carrying a heavy bag. The attacks had resulted in a phobic avoidance of public appearances for which she had been treated with clomipramine by a psychiatrist. She also experienced episodes of stiffening of her right hand with her thumb forced inward. These episodes lasted from minutes to hours and occurred mainly during sustained use of her arm.

Examination - Neurological examination showed normal eye movements without nystagmus, and normal coordination, muscle strength, sensation, and reflexes. Rippling of the skin was present in the first interosseous space of both hands, and pendent fingers showed small semirhythmical, lateral movements.

Witnessed attack-During an attack (provoked by five knee bends) that lasted about three minutes, she had rhythmic involuntary shaking of arms and legs that put her off balance. A finger-to-nose test showed a kinetic tremor and dysmetria. A spontaneous or gaze evoked nystagmus was absent. Half an hour later another attack occurred after 20 knee bends, and showed a gradual build up with continued provocation. Rising quickly after a hand clap failed to provoke an attack.

Treatment and follow up-During treatment with acetazolamide no attacks occurred for three days, but then reappeared once or twice a day, at about half the original frequency. This partial effect remained for over three months. When on acetazolamide treatment, performance of knee bends did not provoke an attack and she was able to engage in new activities. After an interruption of the acetazolamide medication she had many long attacks, again easily provoked by exercise. Prevention of attacks and paraesthesiae were obviously both dose related, with an optimal dose of 187 $\mathrm{mg} /$ day. Paraesthesiae could be reduced by supplementation with $2 \mathrm{~g}$ potassium daily.

\section{Patient 2 (IV-6)}

The 22 year old brother of the proband had experienced attacks of dizziness since the age of 6 years, manifesting limb and gait incoordination and dysarthria. The attacks were brought on by sudden movements, lasted for about two minutes, and happened about once daily. At the age of 15, after a mild head injury, he also developed attacks of stereotyped dystonic movements that lasted about 10 seconds, and occurred up to 20 times a day. Usually, these dystonic movements involved the right arm with variable inclusion of the face and leg, but they also happened in the left arm, or involved both sides. As with the dizziness, these attacks were provoked by sudden rising, limping, and other quick movements, but could also be provoked by voluntary contraction of his right thigh muscles. The dystonic attacks started with paraesthesiae in the ulnar side of the right hand. A vague awareness, lasting many hours, indicated proneness for these dystonic attacks. At times, attacks of dystonia and of ataxia coincided, brought on by the same kinesigenic stimulus. Treatment with $400 \mathrm{mg}$ carbamazepine a day effectively reduced the dystonic attacks to less than one a day, but did not obviously reduce the occurrence of ataxia. The patient had a history of finger trembling that diminished during treatment with fluvoxamine for anxiety.

Examination-Neurological examination with special attention to eye movements and coordination was normal. Myokymia was not detected clinically.

Treatment and follow up-Medication with only $62.5 \mathrm{mg}$ acetazolamide once daily caused pronounced paraesthesiae and was discontinued before its effect could be assessed.

\section{Results}

Figure 1 shows the relevant data on pedigree and genotype. Table 1 shows characteristics of the affected family members. The attacks were first noticed in childhood, showed a maximum in the second decade, and declined with increasing age. Ataxia was often preceded by a sensory warning and usually built up within 10 seconds followed by a more gradual decline. The shaking that accompanied the ataxia could be slight or pronounced. Several circumstances influenced the occurrence of attacks, and people could often sense a certain proneness. Attempts to provoke an attack by repeated knee bends or sudden rising were uncomfortable and often not successful.

\section{EXAMINATION AND WITNESSED ATTACKS}

Apart from the presence of myokymia, neurological examination between attacks was normal in all affected members. Rippling of 
Figure 1 Relevant part of the pedigree. Affected people are represented with black symbols. The genotypic data of chromosome 12p markers are shown below each symbol. The following markers are represented.

$A=D 12 S 100$

$B=D 12 S 372$

$C=D 12 S 1088$,

$D=K C N A 5$, and

$E=D 12 S 99$.

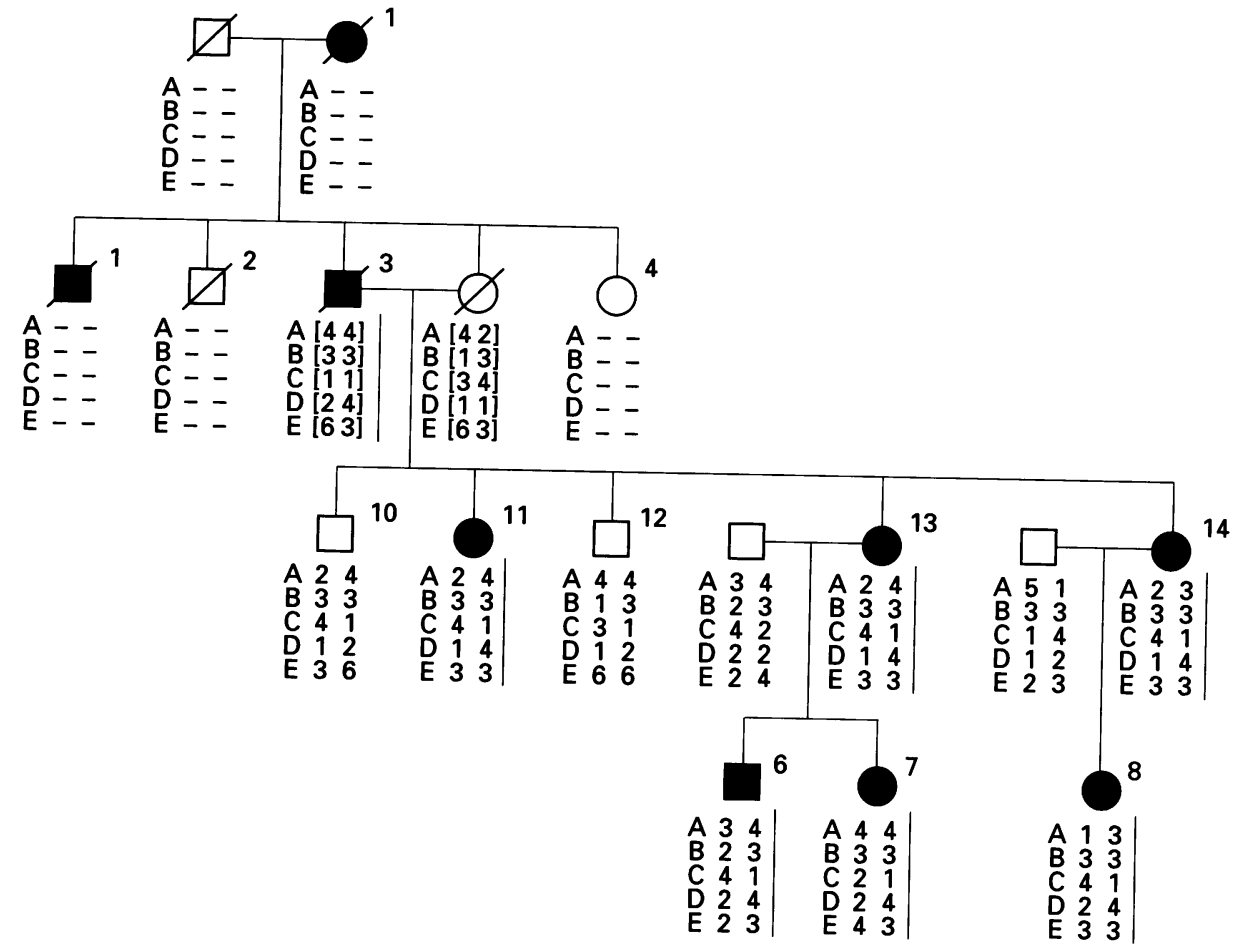

the skin and lateral finger movements indicated myokymia in three of the six patients. In one patient (III-14) the finger movements were semirhythmic in a lateral direction, similar to the appearance of myokymia in the family previously described by us. ${ }^{8}$ In two other patients (IV-7 and IV-8) involuntary activity was different, with intermittent, unpredictable small jerky finger movements that we did not at first recognise as a myokymic manifestation. A minor attack witnessed in patient III-13, consisted of an uncomfortable feeling and inability to move freely but without visible ataxia or tremor.

\section{LACTATE AND PYRUVATE TEST}

Serum lactate and pyruvate concentrations in cases III-13, IV-6, and IV-7 were within the normal range.

\section{ELECTROENCEPHALOGRAPHY}

An EEG of patient IV-7 before and during a provoked attack was normal. An EEG lateralised left temporal slowing, unchanged during provoked attacks of dystonia. registration of patient IV-6 in 1989 showed

Table 1 Data of affected family members

\begin{tabular}{|c|c|c|c|c|c|c|}
\hline & \multicolumn{6}{|l|}{ Patient } \\
\hline & $I I I-11$ & $I I I-13$ & $I I I-14$ & $I V-6^{*}$ & $I V-7$ & $I V-8$ \\
\hline $\begin{array}{l}\text { Age (y) } \\
\text { Ataxia: }\end{array}$ & 52 & 42 & 37 & 22 & 20 & 18 \\
\hline $\begin{array}{l}\text { Age of onset (y) } \\
\text { Attenuation (y) } \\
\text { Frequency } \\
\text { Duration } \\
\text { Sensory aura } \\
\text { Subjective } \\
\text { sensations }\end{array}$ & $\begin{array}{l}\quad 6 \\
>20 \\
2-3 / \text { week } \\
1-5 \text { min } \\
+ \\
\text { Diplopia } \\
\text { Weakness }\end{array}$ & $\begin{array}{l}\quad 6 \\
>16 \\
4-10 / \text { day } \\
1-5 \text { min } \\
+ \\
\text { Nausea } \\
\text { Diplopia } \\
\text { Stiffness }\end{array}$ & $\begin{array}{l}5 \\
? \\
2 / \text { day } \\
1-5 \mathrm{~min} \\
+ \\
\text { Sweating } \\
\text { "Dizziness" }\end{array}$ & $\begin{array}{l}\frac{6}{2-3 / \text { week }} \\
2 \text { min-3 h } \\
+ \\
\text { Oscillopsia } \\
\text { "Dizziness" }\end{array}$ & $\begin{array}{l}\quad 6 \\
>18 \\
3-4 / \text { day } \\
10 \text { s-5-min } \\
+ \\
\text { Nausea } \\
\text { "Dizziness" } \\
\text { Carpal spasm }\end{array}$ & $\begin{array}{l}\quad 4 \\
>17 \\
2-3 / \text { week } \\
2-3 \text { min } \\
+ \\
\text { "Dizziness" }\end{array}$ \\
\hline $\begin{array}{l}\text { Movement } \\
\text { coordination } \\
\text { Provocation: }\end{array}$ & $\begin{array}{l}\text { Gait and limb } \\
\text { ataxia }\end{array}$ & $\begin{array}{l}\text { Gait and limb } \\
\text { ataxia }\end{array}$ & $\begin{array}{l}\text { Gait and limb } \\
\text { ataxia } \\
\text { shaking limbs }\end{array}$ & $\begin{array}{l}\text { Gait and limb } \\
\text { ataxia } \\
\text { jerky movements }\end{array}$ & $\begin{array}{l}\text { Carpal spasm } \\
\text { Gait and limb } \\
\text { ataxia }\end{array}$ & $\begin{array}{l}\text { Gait and limb } \\
\text { ataxia } \\
\text { trembling }\end{array}$ \\
\hline $\begin{array}{l}\text { "Spontaneous" } \\
\text { Sudden movements } \\
\text { Exertion } \\
\text { Additional } \\
\text { influences }\end{array}$ & $\begin{array}{l}+ \\
+ \\
+ \\
\text { Menses } \\
\text { startle }\end{array}$ & $\begin{array}{l}+ \\
+ \\
+ \\
\text { Menses } \\
\text { illness, }\end{array}$ & $\begin{array}{l}+ \\
+ \\
+ \\
\text { Emotional } \\
\text { stress } \\
\text { Smell of food }\end{array}$ & $\begin{array}{l}+ \\
+ \\
- \\
\text { Emotional } \\
\text { stress }\end{array}$ & $\begin{array}{l}+ \\
+ \\
+ \\
\text { Startle }\end{array}$ & $\begin{array}{l}+ \\
+ \\
+ \\
\text { Startle }\end{array}$ \\
\hline $\begin{array}{l}\text { Examination: } \\
\text { Nystagmus } \\
\text { Ataxia }\end{array}$ & - & - & - & - & - & - \\
\hline $\begin{array}{l}\text { Myokymia } \\
\text { Myokymia on EMG } \\
\text { Treatment with } \\
\text { acetazolamide: }\end{array}$ & $\begin{array}{l}- \\
+\end{array}$ & + & $\begin{array}{l}+ \text { (rhythmic) } \\
+\end{array}$ & - & $\begin{array}{l}+ \text { (jerky and } \\
\text { rhythmic) } \\
+\end{array}$ & $\begin{array}{l}+ \text { (jerky and } \\
\text { rhythmic) } \\
+\end{array}$ \\
\hline $\begin{array}{l}\text { Dose (mg) } \\
\text { Effect† }\end{array}$ & $\begin{array}{l}63 \\
?\end{array}$ & $\begin{array}{l}125 \\
+\end{array}$ & $\begin{array}{l}63 \\
+\end{array}$ & $\begin{array}{l}63 \\
?\end{array}$ & $\begin{array}{l}188 \\
+\end{array}$ & $\begin{array}{l}31 \\
?\end{array}$ \\
\hline
\end{tabular}


A

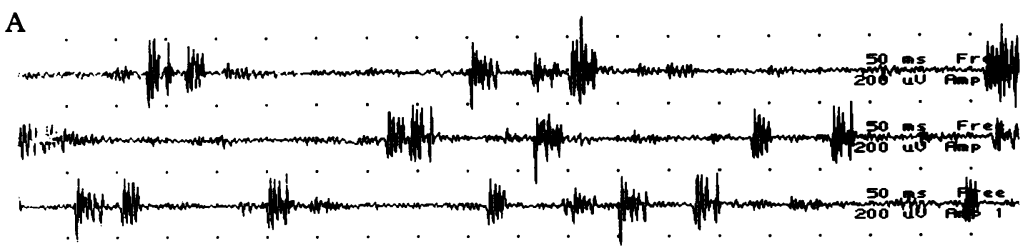

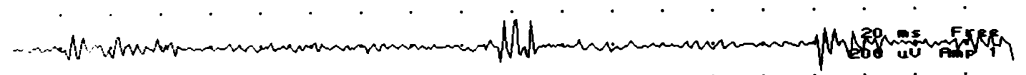

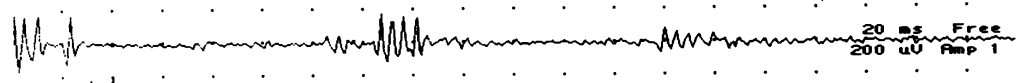

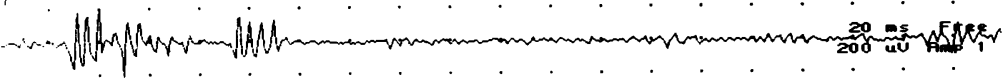

B

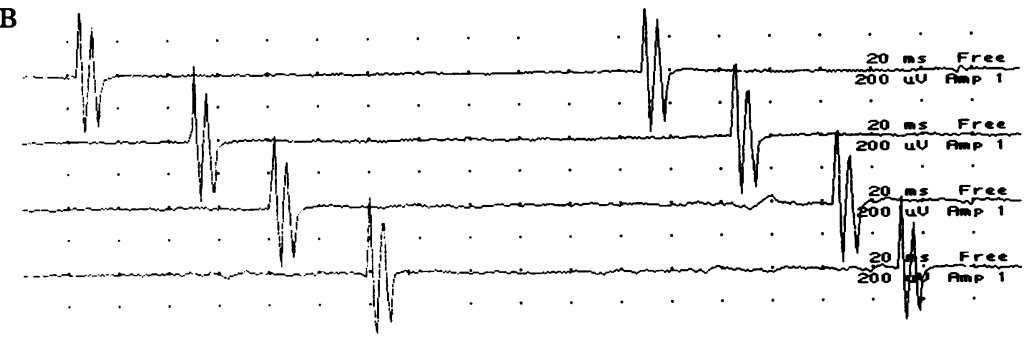

C

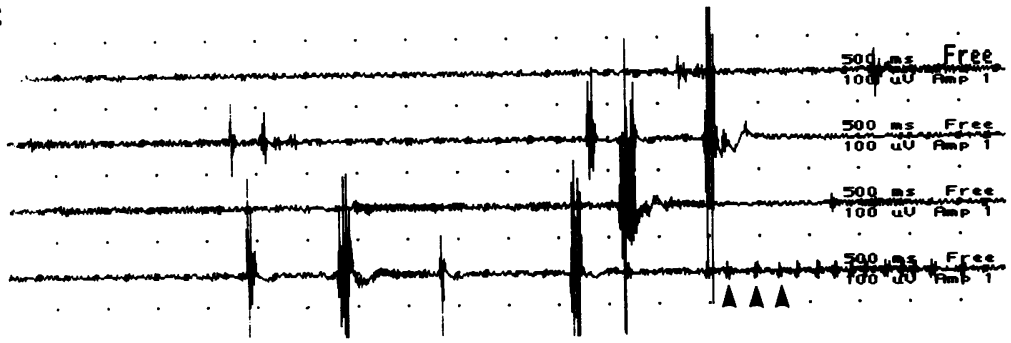

Figure 2 EMG recording of spontaneous muscle activity. (A) Different independently occurring multiplets. Surface recording from muscle abductor pollicis brevis, patient IV-7. (B) Single rhythmically occurring duplet, brought on by three minutes of local ischaemia. Concentric needle recording from muscle abductor digiti quinti, patient IV-6. (C)

Irregularly occurring bursts causing small jerky finger movements. Spontaneous myokymic activity marked by $\boldsymbol{\Delta}$ Surface recording from first dorsal interosseous muscle, patient IV-8.

\section{ELECTROMYOGRAPHY}

All but one (IV-6) of the affected members showed resting EMG activity in the hand and lower arm muscles. In three patients (III-11, III-13, III-14) myokymic activity consisted of rhythmically repeated, independently occurring singlets and multiplets of relatively low amplitude (up to $600 \mu \mathrm{V}$ ), with a frequency of $2-5 / \mathrm{s}$ and a spike interval of 5-10 ms (fig 2A). During three minutes of ischaemia, some myokymic discharges showed a gradual two to threefold rise in frequency, which returned to baseline after deflation. After ischaemia additional myokymic discharges were recruited, and myokymic discharges, in which the fre-

Table 2 Lod scores for the 12p markers

\begin{tabular}{llllllll}
\hline \multicolumn{7}{l}{$\theta$ value } \\
\cline { 2 - 7 } & 0.001 & 0.01 & 0.05 & 0.10 & 0.20 & 0.30 & 0.40 \\
\hline D12S1088 & 0.60 & 0.59 & 0.56 & 0.51 & 0.41 & 0.29 & 0.16 \\
KCNA5 & 2.10 & 2.07 & 1.93 & 1.74 & 1.33 & 0.87 & 0.39 \\
D12S99 & 0.90 & 0.86 & 0.81 & 0.72 & 0.51 & 0.30 & 0.09 \\
\hline
\end{tabular}

No Lod score was calculated for D12S100 due to the occurrence of a new allele in patient III-14. No Lod score was calculated for D12S100 due to the occurrence of a new allele in patient III-14. Marker D12S372 was not informative. The map distances for the quency had risen, increased in length. Volitional contraction during $10-15$ seconds interrupted the myokymic activity for one or two seconds, but a short, jerk-like contraction could start myokymic activity that had not been previously present. In patient IV-6, in whom we were unable to detect myokymia by EMG, three minutes of regional ischaemia brought on typical repetitive myokymic activity (fig 2B). In patients IV-7 and IV-8, with more jerky involuntary finger movements, electromyography showed irregularly repeated complex bursts of about $50-100 \mathrm{~ms}$ with varying shape as well as the repetitive myokymic activity (fig $2 \mathrm{C}$ ).

\section{LINKAGE STUDIES}

With markers closely linked to the hereditary myokymia and paroxysmal ataxia locus, we show linkage in this family to chromosome $12 p$ (fig 1). No crossover was identified, and in patient III-14, a mutation apparently resulted in a new allele for marker D12S100. Table 2 shows the calculated pairwise lod scores for linkage.

Sequencing of the KCNAl gene identified a Glu325Asp missense mutation, detailed findings of which will be presented elsewhere. ${ }^{15}$

\section{TREATMENT AND FOLLOW UP}

Treatment with acetazolamide was initiated in all affected family members. Paraesthesiae occurred in all patients, even at a low dose, and caused the medication to be stopped in three patients with relatively few attacks. The paraesthesiae appeared about 15 minutes after the ingestion of acetazolamide and lasted for several hours. They could be diminished by oral potassium. Parallel to the occurrence of paraesthesiae, two patients noticed increased muscle stiffness. Relatively low doses of $63-188 \mathrm{mg}$ acetazolamide a day were accepted by three patients (IV-7, III-13, and III-14), reducing both the number and the severity of attacks. This effect was obvious from the first day and lasted for about one day after the treatment ended. After one or two weeks of treatment about half of its initial efficacy was gradually lost. Stabilisation followed thereafter.

\section{Discussion}

The syndrome of hereditary myokymia and paroxysmal ataxia in this family compares well with the five families described previously. ${ }^{16-9}$ Table 3 summarises the data. Obviously, the attacks in childhood may initially pass unrecognised. A kinesigenic provocation, occurring in five out of six families with hereditary myokymia and paroxysmal ataxia, may serve to differentiate within the episodic ataxias, although this is not mentioned in recent reviews. ${ }^{311}$ Diminished physical activity and kinesigenic provocation may well play a part in the reduced occurrence of attacks after the teenage years. The presence of a sensory warning, mentioned in two other families with hereditary myokymia and paroxysmal ataxia, 
Table 3 Familial paroxysmal ataxia with continuous myokymia

\begin{tabular}{|c|c|c|c|c|c|c|}
\hline & \multicolumn{6}{|l|}{ Authors } \\
\hline & $\begin{array}{l}\text { Van Dyke } \\
\text { et al }{ }^{6} \\
\text { (1975) }\end{array}$ & $\begin{array}{l}\text { Hanson } \\
\text { et al } \\
\text { (1977) }\end{array}$ & $\begin{array}{l}\text { Gancher } \\
\text { and Nutt } \\
\text { (1986) }\end{array}$ & $\begin{array}{l}\text { Brunt and } \\
\text { Van Weerden } \\
\text { (1990) }\end{array}$ & $\begin{array}{l}\text { Vaamonde } \\
\text { et al } \\
\text { (1991) }\end{array}$ & $\begin{array}{l}\text { Lubbers } \\
\text { et al } \\
\text { (1995) }\end{array}$ \\
\hline $\begin{array}{l}\text { Inheritance } \\
\text { Number: }\end{array}$ & $\mathrm{AD}$ & $\mathrm{AD}$ & $\mathrm{AD}$ & $\mathrm{AD}$ & $\mathrm{AD}$ & $\mathrm{AD}$ \\
\hline $\begin{array}{l}\text { Reported } \\
\text { Examined } \\
\text { Affected }\end{array}$ & $\begin{array}{r}3 \\
7\end{array}$ & $\begin{array}{l}3 \\
3 \\
4\end{array}$ & $\begin{array}{r}3 \\
7 \\
15\end{array}$ & $\begin{array}{l}22 \\
22 \\
28\end{array}$ & $\begin{array}{l}3 \\
1 \\
3\end{array}$ & $\begin{array}{l}6 \\
6 \\
9\end{array}$ \\
\hline $\begin{array}{l}\text { Affected } \\
\text { Ataxia: }\end{array}$ & 11 & & & & & 9 \\
\hline $\begin{array}{l}\text { Age of onset (y) } \\
\text { Attenuation (y) } \\
\text { Frequency } \\
\text { Duration }\end{array}$ & $\begin{array}{l}2-12 \\
? \\
0-10 / \text { day } \\
\pm 3 \text { min }\end{array}$ & $\begin{array}{l}4-8 \\
? \\
0-1 / \text { day } \\
10-15 \mathrm{~min}\end{array}$ & $\begin{array}{l}6-15 \\
>20 \\
0-2 / \text { day } \\
\pm 2 \text { min }\end{array}$ & $\begin{array}{l}2-15 \\
20-50 \\
0-15 / \text { day } \\
10 \mathrm{~s}-10 \mathrm{~min} \\
\text { (up to } 6 \mathrm{~h} \text { ) }\end{array}$ & $\begin{array}{l}6 \\
? \\
0-3 / \text { week } \\
\text { few min }\end{array}$ & $\begin{array}{l}4-6 \\
>20 \\
0-10 / \text { day } \\
10 \mathrm{~s}-5 \text { min } \\
\text { (up to } 3 \mathrm{~h} \text { ) }\end{array}$ \\
\hline $\begin{array}{l}\text { Sensory aura } \\
\text { Subjective }\end{array}$ & + & $?$ & $?$ & + & $?$ & + \\
\hline $\begin{array}{l}\text { Movements, } \\
\text { coordination }\end{array}$ & $\begin{array}{l}\text { Vertigo, } \\
\text { diplopia, } \\
\text { blurred vision } \\
\text { Generalised } \\
\text { ataxia, } \\
\text { jerking, nodding } \\
\text { of head and arms }\end{array}$ & $\begin{array}{l}\text { Eyes drawn } \\
\text { backward, } \\
\text { weakness legs } \\
\text { Generalised } \\
\text { ataxia, } \\
\text { shaking, } \\
\text { s staggering }\end{array}$ & $\begin{array}{l}\text { Weightlessness, } \\
\text { sensation of } \\
\text { falling } \\
\text { Generalised } \\
\text { ataxia, } \\
\text { tremor? }\end{array}$ & $\begin{array}{l}\text { Limb stiffness, } \\
\text { heavy feeling, } \\
\text { 士blurred vision } \\
\text { Generalised } \\
\text { ataxia, } \\
\text { postural tremor } \\
\text { of head and arms }\end{array}$ & $\begin{array}{l}\text { Blurred vision } \\
\text { Generalised } \\
\text { ataxia?, } \\
\text { jerking }\end{array}$ & $\begin{array}{l}\text { Dizziness } \\
\text { weakness, } \\
\text { stiffness } \\
\text { Generalised } \\
\text { ataxia, } \\
\text { shaking } \\
\text { trembling }\end{array}$ \\
\hline Provocation & $\begin{array}{l}\text { Generalised } \\
\text { myokymia, } \\
\text { carpal spasm } \\
\text { Kinesigenic + } \\
\text { caloric } \\
\text { stimulation + }\end{array}$ & $\begin{array}{l}\text { Stiffening, } \\
\text { cramp in body, } \\
\text { arms and hands } \\
\text { Kinesigenic + } \\
\text { caloric } \\
\text { stimulation - }\end{array}$ & $\begin{array}{l}\text { Limb muscles } \\
\text { twitching, } \\
\text { puckering mouth } \\
\text { Kinesigenic ? } \\
\text { exercise }\end{array}$ & $\begin{array}{l}\text { Few: stiffening } \\
\text { hands } \\
\text { Kinesigenic + }\end{array}$ & $\begin{array}{l}\text { Spasm hand } \\
\text { and foot } \\
\text { Kinesigenic + }\end{array}$ & $\begin{array}{l}\text { Stiffening } \\
\text { hands, } \\
\text { carpal spasm } \\
\text { Kinesigenic + } \\
\text { exercise }\end{array}$ \\
\hline $\begin{array}{l}\text { Additional } \\
\text { influences }\end{array}$ & $\begin{array}{l}\text { Hunger, fatigue } \\
\text { excitement, } \\
\text { anxiety }\end{array}$ & $\begin{array}{l}\text { Perimenstrual } \\
\text { illness }\end{array}$ & $\begin{array}{l}\text { Stress, fatigue, } \\
\text { excitement }\end{array}$ & $\begin{array}{l}\text { Startle, } \\
\text { anxiousness, } \\
\text { illness }\end{array}$ & $\begin{array}{l}\text { Stress, fatigue, } \\
\text { hyperventilation, } \\
\text { illness }\end{array}$ & $\begin{array}{l}\text { Startle, } \\
\text { perimenstrual } \\
\text { illness }\end{array}$ \\
\hline Interval examination: & - & - & - & - & - & - \\
\hline $\begin{array}{l}\text { Ataxia } \\
\text { Myokymia }\end{array}$ & $\begin{array}{l}\text { ? } \\
\text { Face, hands, } \\
\text { moving fingers, } \\
\text { carpal spasm, } \\
\text { calf hypertrophy }\end{array}$ & $\begin{array}{l}\text { ? } \\
\text { Resting tremor } \\
\text { in body, hands } \\
\text { (contractures) }\end{array}$ & $\begin{array}{l}\text { ? } \\
\text { Face } \\
\text { distal limbs, } \\
\text { moving fingers }\end{array}$ & $\begin{array}{l} \pm: \text { few, }>50 \mathrm{y} \\
\text { Face, hands, } \\
\text { pending finger } \\
\text { movements } \\
\text { (thumb adduction }\end{array}$ & 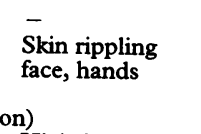 & $\begin{array}{l}\text { Face, fingers, } \\
\text { regular/jerky } \\
\text { movements }\end{array}$ \\
\hline Treatment: & CMUA & $\begin{array}{l}\text { CMUA, } \\
\text { Neuromyotonia }\end{array}$ & $\begin{array}{l}\text { Neuromyotonia } \\
\text { repetitive grouped } \\
\text { discharges }\end{array}$ & $\begin{array}{l}\text { Irregular/regular } \\
\text { d repetitive singlets } \\
\text { multiplets }\end{array}$ & $\begin{array}{l}\text { High frequency } \\
\text { irregular singlets } \\
\text { multiplets }\end{array}$ & $\begin{array}{l}\text { irregular/regular } \\
\text { repetitive singlets, } \\
\text { multiplets } \\
\text { (postischaemic) }\end{array}$ \\
\hline $\begin{array}{l}\text { Phenytoin } \\
\text { Acetazolamide }\end{array}$ & $\begin{array}{l}\text { Ataxia } \downarrow \\
\text { Myokymia } \rightarrow \\
? \\
?\end{array}$ & $\begin{array}{l}\text { Ataxia } \downarrow \\
\text { Myokymia } \rightarrow \\
? \\
?\end{array}$ & $\begin{array}{l}\text { Ataxia } \rightarrow \\
\text { Myokymia } \downarrow \\
\text { Ataxia } \rightarrow \\
\text { Myokymia? }\end{array}$ & $\begin{array}{l}\text { Ataxia } \rightarrow \\
\text { Myokymia? } \\
\text { Ataxia } \downarrow \\
\text { Myokymia } \uparrow\end{array}$ & $\begin{array}{l}\text { Ataxia ? } \\
\text { Myokymia? } \\
\text { Ataxia } \rightarrow \\
\text { Myokymia? }\end{array}$ & $\begin{array}{l}\text { ? } \\
\text { ?taxia } \downarrow \\
\text { Myokymia } \uparrow\end{array}$ \\
\hline
\end{tabular}

and at times experienced by all members of the present family seems to be another feature that differentiates attacks in hereditary myokymia and paroxysmal ataxia from those in familial periodic ataxia.

The shaking of legs and trunk during an attack shown by one of the members of the present family was more pronounced than previously found by us, but has also been described in two other families with hereditary myokymia and paroxysmal ataxia. ${ }^{6-8}$ The normal, unaltered EEG during one of the provoked attacks and the normal pyruvate and lactate are in line with previous findings. ${ }^{6}$ The clinical and EMG manifestation and the reactivity of myokymia in this family compare well with our previously described family, with the exception of the irregular, choreiform jerky finger movements and non-repetitive long bursts on EMG in two affected members. ${ }^{8}$ The provocation of myokymia by local ischaemia during three minutes extends the reported enhancement of myokymia after ischaemia, and seems to be a simple test to support the diagnosis in patients suspected to have hereditary myokymia and paroxysmal ataxia who have no spontaneous myokymic activity. In the EMG examination with surface electrodes on more than 25 affected people we have not previously encountered absence of myokymic activity, although we found a wide variation between patients and over time. Myokymic activity brought about by ischaemia also widens this range. Obviously the amount of myokymic activity also varies between families.

Genetic linkage of episodic ataxia and myokymia (hereditary myokymia and paroxysmal ataxia) to loci D12S91, D12S100, CACNL1A1, D12S372, pY21-1 (=D12S1088), KCNA5, D12S93, and D12S99 on chromosome $12 \mathrm{p}$ was shown previously. ${ }^{12}$ The linkage to the episodic ataxia and myokymia locus and the finding of another missense mutation in the KCNA1 gene groups this family with those previously described. ${ }^{12-13}$

The prevention of attacks of ataxia by acetazolamide in this family confirms our previous findings in hereditary myokymia and paroxysmal ataxia. ${ }^{8} \mathrm{~A}$ reduced efficacy after some weeks has also been found in some patients of the first family that we studied. The early decline followed by a prolonged remaining efficacy suggests a metabolic adaptation rather than a placebo effect, but we have not found changes in laboratory values. The suppressive effect of acetazolamide may not occur in all families with hereditary myokymia and paroxysmal ataxia, but clearly 
prevents its use to differentiate hereditary myokymia and paroxysmal ataxia from familial periodic ataxia as recently suggested. ${ }^{1911}$ Although not separating episodic ataxias with and without myokymia, Ptáček, commenting on the discovery of the KCNAl channel mutation in hereditary myokymia and paroxysmal ataxia, drew attention to the shared favourable reaction to acetazolamide of diseases caused by mutations in cation channels. ${ }^{16}$ The early occurrence of paraesthesiae and increase in muscle stiffness after the use of acetazolamide confirm earlier findings, and suggest an abnormal sensitivity to acetazolamide as part of the hereditary myokymia and paroxysmal ataxia syndrome. ${ }^{8}$ We did not use phenytoin, which proved effective in two of the other families with hereditary myokymia and paroxysmal ataxia, in the present family. ${ }^{67}$ The occurrence of attacks of paroxysmal kinesigenic choreoathetosis in one affected member (IV-6) is remarkable. The rarity of both conditions and the shared provocation suggest a relation, but the occurrence after a head trauma and different reaction to carbamazepine may argue for a different aetiology. ${ }^{171819}$ Gancher and Nutt have described one family (kindred V) in whom attacks of kinesigenic episodic ataxias and of paroxysmal kinesigenic choreoathetosis occurred separately in some members, and jointly in one ${ }^{1}$ : in this person, the early manifestation of attacks of episodic ataxia at the age of 6 years, followed by the occurrence of attacks of paroxysmal kinesigenic choreoathetosis at the age of 15 years, closely parallel the temporal sequence in our case IV-7. The presence of myokymia in this family was not obvious at the time of this report, but was found later in some affected members (J Nutt, personal communication).

The observation of a second patient who had combined attacks of hereditary myokymia and paroxysmal ataxia and of paroxysmal kinesigenic choreoathetosis strengthens the suggestion that occurrence of these two types of attacks is not mere coincidence. Also, previous reports on episodic dystonia occurring in two families with progressive ataxia suggest a possible relation. ${ }^{2021}$
We thank Dr Nigel Jack for correction of the language, and Eveline Eimers for secretarial support.

1 Gancher ST, Nutt JG. Autosomal dominant episodic ataxia: a heterogeneous syndrome. Mov Disord 1986;1: 239-53.

2 Parker HL. Periodic ataxia. Collected papers from the Mayo Clinic 1946;38:642-5.

3 Moon SL, Koller WC. Hereditary periodic ataxias. In: De Jong JMBV, ed. Handbook of clinical neurology. Vol 16(60). Hereditary neuropathies and spinocerebellar atrophies. Amsterdam: Elsevier, 1991:433-43.

4 Griggs RC, Moxley RT, Lafrance RA, McQuillen J. Hereditary paroxysmal ataxia: response to acetazolamide. Neurology 1978;28:1259-64.

5 Wolf P. Familiäre episodische Ataxia. Nervenarzt 1980;51: 355-8.

6 Van Dyke DH, Griggs RC, Murphy MJ, Goldstein MN. Hereditary myokymia and periodic ataxia. $\mathcal{f}$ Neurol $\mathrm{Sci}$ 1975;25:109-18.

7 Hanson PA, Martinez LB, Cassidy R. Contractures, continuous muscle discharges and titubation. Ann Neurol 1977;1:120-4.

8 Brunt ERP, Van Weerden TW. Familial paroxysmal ataxia and continuous myokymia. Brain 1990;113:1361-82.

9 Vaamonde J, Artieda J, Obeso JA. Hereditary paroxysmal ataxia with neuromyokymia. Mov Disord 1991;6:180-2.

10 Brunt ERP, Van Weerden TW. Distal axonal origin and motor unit involvement in myokymia [abstract]. Neurology 1994;44(suppl 2):A411.

$11 \mathrm{Fahn} S$. The paroxysmal dyskinesias. In: Marsden CD, Fahn S, eds. Movement disorders 3. Oxford: ButterworthHeinemann, 1994:319-20.

12 Litt M, Browne D, Kramer P, Gancher S, Brunt ERP, Root $\mathrm{D}$, et al. A gene for episodic ataxia/myokymia maps to chromosome 12p13. Am f Hum Genet 1994;55: 702-9.

13 Browne DL, Gancher ST, Nutt JG, Brunt ERP, Smith EA, Kramer P, Litt M. Episodic ataxia/myokymia syndrome is associated with point mutations in the human potassium channel gene KCNA1. Nature Genetics 1994;8:136-40.

14 Zierz S, Meessen S, Jerusalem F. Lactat- und Pyruvatspiegel in der Diagnostik mitochondrialer Myopathien. Nervenartzt 1989;60:545-8.

15 Browne DL, Brunt ERP, Griggs RC, Nutt JG, Gancher ST, Smith EA, Litt M. Identification of two new KCNAl mutations in episodic ataxia/myokymia families. Hum Mol Genet 1995 (in press).

16 Ptáček LJ. Ion channel shake-down. Nature Genetics 1994;8:111-2.

17 Robin JJ. Paroxysmal choreoathetosis following head injury. Ann Neurol 1977;2:447-8.

18 Drake ME, Jackson RD, Miller CA. Paroxysmal choreoathetosis after head injury [letter]. I Neurol Neurosurg Psychiatry 1986;49:837-8.

19 Richardson JC, Howes JL, Celinski MJ, Allman RG. Kinesiogenic choreoathetosis due to brain injury. Can $\dot{f}$ Neurol Sci 1987;14:626-8.

20 Mayeux R, Fahn S. Paroxysmal dystonic choreoathetosis in a patient with familial ataxia. Neurology 1982;32: $1184-6$.

21 Graff-Radford NR. A recessively inherited ataxia with episodes of dystonia. $\mathcal{F}$ Neurol Neurosurg Psychiatry 1986; 49:591-4. 